\title{
On the Politeness in College English Teachers’ Classroom Talk*
}

\author{
XI Hong-mei, SONG Hong, QU Ying, LIU Dan \\ Harbin Engineering University, Harbin, China
}

\begin{abstract}
Teachers' talk is an important aspect for conducting college English class effectively. It plays crucial roles in giving instructions, organizing classroom norm, and facilitating students' language acquisition. Based on Leech's Politeness Principle, this paper has analyzed the politeness in teachers' classroom talk and explored the functions it possesses as well. The study shows that the politeness feature of college English teachers' classroom talk is the consequences of observing each maxim of the Politeness Principle and is of the functions such as making effective commnication, keeping friendly relations with students, saving students' face, etc.. Conducting research on politeness in teachers' talk is conducive to understanding the process of language teaching and learning.
\end{abstract}

Keywords: teachers’ talk, politeness, Politeness Principle

\section{Introduction}

Since the mid 1990s, "teacher research” has been put forward by many Western researchers. In this field, teachers' talk attracts great attention. The studies mostly focus on various features of teachers' talk as a language input, such as speech rate, pause, intonation, accent, and adjustment in the aspects of vocabulary, syntax, and discourse. Cook (2000) did some research about the amount of teachers' speech in language classes, while many researchers did similar research on both the first and the second language learning classes. Moreover, research on teachers' talk in the classroom settings, especially on teachers' speech acts, also aroused a hot topic at home and abroad. Wubbels and his colleagues (Williams \& Burden, 2000) embarked on a series of studies about the association between learners' learning outcomes and their perceptions of their teachers' interpersonal behavior. They found that interpersonal behavior is an important contributor to learners' cognitive and affective outcomes. W. Lewis Johnson and Paola Rizzo (2004) believed that a model of politeness into the tutoring system should be implemented to achieve the affective goals. Their works build a socially intelligent pedagogical agent helpful for English language teaching.

Following the politeness theory, Chinese scholars have explored the politeness phenomenon in college English teaching from the angle of teachers' discourse, but little attention is paid to its pragmatic principles and functions. This paper attaches great importance to the analysis of the politeness phenomenon and their pragmatic functions by using Leech's Politeness Principle, in order to shed light on the significance of politeness in college

\footnotetext{
* This paper was funded by Heilongjiang Provincial Teaching Reform Project (JG2013010216), Fundamental Research Funds for the Central Universities (HEUCF151218), and Heilongjiang Humanities and Social Sciences Project (No.12534040).

XI Hong-mei, professor, master, Foreign Languages Department, Harbin Engineering University.

SONG Hong, associate professor, Ph.D., Foreign Languages Department, Harbin Engineering University.

QU Ying, lecturer, master, Foreign Languages Department, Harbin Engineering University.

LIU Dan, lecturer, master, Foreign Languages Department, Harbin Engineering University.
} 
English teachers’ discourse and help people better understand English language teaching.

\section{A General Study on Politeness}

Politeness is a rule of life in the daily communication with moral and ethical significance. It is people's efforts to maintain harmonious interpersonal relationships. The goal of politeness is to reflect or realize the social or interpersonal function of language with politeness being "a system of interpersonal relations designed to facilitate interaction by minimizing the potential for conflict and confrontation inherent in all human interchange” (Lakoff, 1990, p. 34).

According to George Yule (2000), politeness, in an interaction, can be defined as the means employed to show awareness of another person's face, which means the public self-image a person claims for himself. That is to say, the function of linguistic politeness is to protect the face from being damaged or to minimize the damaging degree of the face threatening acts. It can be accomplished in situations of social distance and closeness.

The classification of politeness can be dated back to the concept of face. Face theory was first proposed by Goffman. He thought face was not a private property of the individuals, but an image supported by other people's judgments (Goffman, 1967). Based on the concept of face, the British social anthropologists Penelope Brown and Stephen Levinson (1987) identified two kinds of politeness: negative politeness and positive politeness.

Negative politeness is defined as making a request less infringing to maintain negative face, such as "If you don't mind...” or "If it isn't too much trouble...”. Positive politeness means to establish a positive relationship between parties. It respects a person's need to be liked and understood. Positive politeness is oriented toward the positive face and tends to show solidarity, emphasizing that both the speaker and the hearer want the same thing, and that they appeal to a common goal including even friendship or membership.

\section{Leech's Politeness Principle}

As Grice's Cooperative Principle cannot explain why people usually break it in their daily conversation, and it is often observed that one participant's violation of the Cooperative Principle and its maxims is out of politeness, Leech (1983) put forward the Politeness Principle. In Leech's Politeness Principle, politeness concerns a relationship between two parties or sides whom he may call self and other. The main maxims of the Politeness Principle are: Tact, Generosity, Approbation, Modest, Agreement, and Sympathy. Leech noted that in his Politeness Principle and maxims, there is a more general law that politeness is focused more strongly on other than on self within each maxim. So speakers should try to make others benefit more so as to show politeness and win appreciation from others.

\section{Analysis of Politeness in College English Teachers' Classroom Talk}

\section{Observing the Tact Maxim and the Generosity Maxim}

From the maxims of the Politeness Principle mentioned above, it can be seen that the Tact Maxim and the Generosity Maxim respectively concern the cost or benefit of one's future action to other and to self. The former looks from the angle of other's interests, while the latter is from self's benefits, which is to minimize benefit and maximize cost to self. 
It is observed that teachers often combine conventional direct-based teaching methods and other indirect polite speech. Such sentences as "Will you follow me please?" "Would you like to do the exercises?" and "Shall we read the new words together?” are common in college English class. These indirect speech acts not only reduce the degree of enforcement on the students and give students certain rights of choice, but also effect equal communication between teachers and students. They minimize cost to the students, thus closing the relation of the two parties and motivating students' enthusiasm of participation into teaching activities.

Investigation also finds that teachers sometimes fill additional words in the back of their controlling speech acts, like “all right”, “OK”, “please”, and so on. For example, “You two practice the dialogue, OK?” "Don’t make much noise, all right?” “Go on, please.” "Look at the last line, please.” The use of "all right” or "OK” enhances exploratory and speculative tone of voice. In addition, teachers use such words to get prior consent from the students and to seek cooperation with the students, which minimize cost to the students and maximize cost to self.

\section{Observing the Approbation Maxim and the Modesty Maxim}

The Approbation Maxim and the Modesty Maxim respectively concern the degree to which speaker's remarks convey some good or bad evaluation of other and of self. The core of Approbation Maxim is to minimize dispraise and maximize praise of other. It is said that to praise students for recognition of their success is far more important than to correct them because of their failure.

For example, do not forget to use "Very good!”, “Excellent!” to inspire students who answer well; use "Good", "Well-done" to praise students who perform in general. Let them taste the joy of success and inspire their interests in English learning. These different levels of credit word to make corresponding evaluation of the students' response observe the approbation maxim and show teachers' appreciation of students' perspectives, thereby promoting their enthusiasm.

Investigation finds that teachers often choose common words in front of their controlling speech acts to show proper respect of students' views and ingeniously express their opinions, such as "I think", "I suppose”, "I advise”, “I'm afraid”, and “I suggest”. The additional common words reflect teachers' consideration of politeness in their discourse: euphemism, suggestions, modesty, and not a mandatory order implemented on students' activities. They use modesty maxim to help maintain students' face and lead them to various correct answers.

\section{Observing the Agreement Maxim and the Sympathy Maxim}

Harmonious and coherent relations between teachers and students help to mobilize the classroom atmosphere. It is often observed that teachers give feedback in the following way: "It's generally suggested to do that way." "I partially agree, but who has any other ideas?” "Well, you may be right, but I think we can answer this question from another aspect.” The use of hedge "generally” not only softens teachers' tone and weakens disagreement between teacher and students, but also encourages students to have their own special views between the lines. The latter two sentences give direct comments but do not deny the answer completely. "Partially agree" and "may be right" use agreement maxim not only to maintain positive face of the student but also let him realize the impartiality of the answer to encourage deep thinking.

The core of the sympathy maxim is to reduce the affective confrontation of the two communicative parties. Here is a teaching example of observing sympathy maxim to show care for the students. A student failed the exam and could not overcome the feeling of being upset. She told the teacher about her bad mood and got the 
following answer from the teacher, "I know what it is like. You have all my sympathy. Never mind. You can make it next time. I believe in you.”

\section{Pragmatic Functions of the Politeness in English Teachers’ Talk}

\section{Making Effective Communication}

The politeness maxims discussed above are especially important means to avoid any potential face affront to the students. The following is an example of observance of the sympathy maxim to make effective communication: When a student behaves wrongly, the teacher should say "He needs to be brought back into the mainstream" instead of saying "He must be taught right from wrong”. By minimizing antipathy and maximizing sympathy, the teacher not only enables the student to take the hint, but also protects self-esteem of the student, thus obtaining the communicational goal.

By using approbation maxim, teachers show appreciation of the students and cooperation with them to meet the needs of students' positive face. Meanwhile, teachers, as the controlling party of teaching, should make full use of mild language, so that students feel they are not forced to learn and left to a certain degree of personal space. So proper using of tact maxim can help avoid embarrassment during interaction for smooth communication.

\section{Keeping Friendly Relations}

Social communication is generally oriented towards maintaining face and being polite, and one of the ground rules on social communication is a tacit agreement between different parties that everyone should operate with the Politeness Principle in mind. Appropriate use of politeness maxims in college English teaching can make the class polite and build a harmonious relation between teachers and students.

For example, by means of approbation maxim, teachers give certain approval and recognition to students' diligent working attitude, and affirm their achievements and progress to meet the needs of students' positive face. Words of encouragement make students feel they have been steadily progressing, thereby eliminating tension of fear and creating friendly relations between students and teachers.

\section{Saving Students’ Face}

In China, college students, born after the 1980s in particular, value highly the issue of face. With China's tremendous development, they live in exposure to domestic and international arrival of large amounts of information, which broadens their horizons, and makes their thinking active with strong motivation of achievement and recognition. Therefore, in daily teaching, teachers should take the psyche of the students into full consideration, in particular their face and standardize their own language to give less pressure to students and avoid harm to their reputation.

For example, when evaluating a student, "a stupid student” is often replaced by "a slow learner" or "underachiever"; when talking about a below-average student, "he is working at his own level" or "he can do better work with help" is better than directly saying "a student is slow or stupid”; when a student often cheats in class, it is better to say "he is likely to depend on others to do his work". These euphemisms used above to criticize these students can not only play an educational role, but also maintain self-esteem of students, thus saving students' face and harmonizing the classroom atmosphere. Moreover, the students will also remember with reverence to behave well, so that the education effect can really get its results. 


\section{Conclusion}

Teachers' talk acts as an important communicative medium in college English class. It is not only a tool for teachers to implement teaching programs, but also an important source of language input for the students. Whether teachers' discourse is polite or not is an important contributor to learners' cognitive and affective outcomes. Leech's Politeness Principle gives a good interpretation of the politeness in college English teachers' classroom talk. It can carry effective communication to promote teaching activities to move smoothly, which in turn improves the quality of classroom teaching. Moreover, it can harmonize relations between teachers and students and help maintain students' face.

All in all, proper means of human cognition, thinking, and emotional exchange of information and communication are necessary in teachers' discourse. Polite language of English, its pragmatic functions, grammar rules, and statements of the convention not only exist among human communication, but are always reflected in the practice of college English teaching to influence teaching goals. Therefore, changes in teaching concepts and advocacy of functional teaching help students get full knowledge of language and obtain better communication skills.

\section{References}

Brown, P., \& Levinson, S. (1987). Universals in language usage: Politeness phenomenon. Cambridge: Cambridge University Press.

Cook, V. (2000). Second language learning and language teaching. Beijing: Foreign Language Teaching and Research Press.

Goffman, E. (1967). Interaction ritual. New York: Doubleday Anchor.

Johnson, W. L., \& Rizzo, P. (2004). Politeness in the tutoring dialogs: "Run the factory, that's what I'd do". Lecture Notes in Computer Science, 67.

Lakoff, R. T. (1990). Talking power. New York: Basic Books.

Leech, G. N. (1983). Principles of pragmatics. Landon: Longman.

Williams, M., \& Burden, R. L. (2000). Psychology for language teachers. Beijing: Foreign Language Teaching and Research Press.

Yule, G. (2000). Pragmatics. Shanghai: Shanghai Foreign Language Education Press. 